\title{
Perilaku Moral Dan Pendidikan Karakter Pada Keluarga Broken Home Terhadap Kenakalan Remaja Di Wilayah Jakarta Barat
}

\section{Moral Behavior and Character Education in Broken Home Families Against Juvenile Delinquency in the West Jakarta Region}

\author{
Rudy Budiatmaja ${ }^{1)^{*}}$ \\ 1) STTB The Way Jakarta \\ *Penulis Korespondensi: rudybudiatmajasttbtheway@gmail.com
}

Received: 2508 2021/ Accepted: 1811 2021/ Published: 06122021

\begin{abstract}
Abstrak
Penelitian ini bertujuan melihat seberapa jauh pengaruh perilaku moral dan pendidikan karakter pada keluarga broken home terhadap kenakalan remaja serta memberikan solusi yang terbaik untuk meminimalkan kenakalan remaja untuk generasi berikutnya. Metode yang digunakan dalam penelitian ini adalah wawancara singkat dan penelitian ini bersifat kualitatif berupa riset kepustakaan menggunakan metode analisis isi (content analysis). Hasil penelitian ini menunjukkan bahwa peran orangtua termasuk keluarga yang broken home merupakan hal terpenting dalam mengedukasi masalah remaja. Melalui orangtua, remaja diberikan dasar pendidikan perilaku moral yang baik, dan pendidikan karakter untuk usia remaja sangat diperlukan saat ini. Lingkungan juga turut mendukung dalam menjadikan pribadi remaja yang cukup baik. Lingkungan tersebut bisa berasal dari lingkungan tempat tinggal dan lingkungan sekolah. Peran guru di lingkungan sekolah juga sangat penting dalam memberikan pembentukan perilaku moral yang baik dan pendidikan karakter yang berkepribadian yang baik dalam mencegah kenakalan remaja. Dalam penelitian ini bahwa peran orangtua dan guru atas perilaku moral dan pendidikan karakter masih sangat berpengaruh bagi keluarga broken home terhadap kenakalan remaja.
\end{abstract}

Kata-kata Kunci: Broke Home, Keluarga, Kenakalan Remaja, Pendidikan Karakter, Perilaku Moral.

\begin{abstract}
This research aims to see how far the influence of moral behavior and character education in broken home families on juvenile delinquency and to provide the best solution to minimize juvenile delinquency for the next generation. The method used in this study is a short interview and this research is qualitative in the form of library
\end{abstract}


research using content analysis methods. The results of this study indicate that the role of parents, including families with broken homes, is the most important thing in educating adolescent problems. Through parents, teenagers are given the basis for good moral behavior education, and character education for teenagers is very much needed at this time. the environment also supports in making teenagers who are quite good. The environment can come from the neighborhood and the school environment. The role of the teacher in the school environment is also very important in providing the formation of good moral behavior and character education with a good personality in preventing juvenile delinquency.In this study, the role of parents and teachers on moral behavior and character education is still very influential for broken home families against juvenile delinquency.

Keywords: Adolescent Delinquency, Broken Home, Character Education, Family, Moral Behavior.

\section{PENDAHULUAN}

Kenakalan remaja di berbagai kota besar makin mengkhawatirkan, bahkan menyebabkan kehilangan nyawa. Erlinda mengatakan perlunya pemerintah daerah menciptakan ruang terbuka bagi masyarakat untuk saling berkomunikasi. Kasus kenakalan remaja, termasuk tawuran pelajar, seringkali terjadi akibat komunikasi yang buruk antaranggota masyarakat. Anak-anak tidak tersalurkan minat dan bakatnya. Pola pendidikan moral dan keluarga broken home terhadap fenomena kenakalan remaja juga menjadi salah satu faktor pemicu (Erlinda, 2017).

Fenomena kenakalan remaja yang terjadi saat ini adalah sebagai berikut. Jumlah kasus kenakalan remaja tahun 2016 mencapai 8597.97 kasus, 2017 sebesar 9523.97 kasus, 2018 sebanyak 10549.70 kasus, 2019 mencapai 11685,90 kasus dan pada tahun 2020 mencapai 12944,47 kasus. Mengalami kenaikan tiap tahunnya sebesar 10,7\%.

Inilah problem sosial yang menerpa beberapa remaja kita sekarang ini, yaitu tingkah laku menyimpang yang dicap sebagai kenakalan remaja. Adapun penyebab masalah kenakalan remaja diakibatkan dari berbagai macam persoalan, bisa akibat dari kesalahan orangtua di dalam cara mendidik atau orangtua yang terlampau sibuk dengan pekerjaannya. Bahkan keluarga yang broken home, juga dapat dikarenakan tidak tepatnya saat memilih teman/lingkungan pergaulan hingga dapat mengakibatkan terjerumusnya korban ke dalam pergaulan yang salah ataupun akibat dari indivudunya sendiri dikarenakan mengalami krisis identitas (Unayah dan Muslim, 2015).

Kenakalan remaja pada saat ini akibat keluarga broken home seperti yang banyak diberitakan di berbagai media, sudah dikatakan melebihi batas yang sewajarnya. Banyak anak remaja dan anak di bawah umur sudah mengenal rokok, 
narkoba, free sex, tawuran, pencurian, dan terlibat banyak tindakan kriminal lainnya yang menyimpang dari norma-norma yang berlaku di masyarakat dan berurusan dengan hukum.

Orangtua berperan dalam pertumbuhan anak mulai dari bayi sampai dewasa. Orangtua sebagai pendidik dan pembimbing utama dalam hal kepribadian anak. Kepribadian akan berkembang menjadi karakter ketika seseorang mempelajari kelebihan dan kelemahan dirinya (Wahid, 2015).

Rumusan masalah dalam penelitian ini dilakukan dengan tujuan untuk melakukan dan mengkaji lebih dalam yang merupakan studi kasus seberapa besar pengaruh perilaku moral dan pendidikan karakter pada 50 keluarga broken home terhadap kenakalan remaja di wilayah Jakarta Barat dan bagaimana solusi terbaiknya agar bisa meminimalkan kenakalan remaja untuk generasi berikutnya.

\section{TEORI}

\section{Utilitarianisme Theory}

Utilitarianisme berasal dari kata Latin utilis, kemudian menjadi kata Inggris utility yang berarti bermanfaat (Bertens, 2013). Menurut teori ini, suatu tindakan dapat dikatakan baik jika membawa manfaat bagi sebanyak mungkin anggota masyarakat, atau dengan istilah yang sangat terkenal "the greatest happiness of the greatest numbers". Perbedaan paham utilitarianisme dengan paham egoisme etis terletak pada siapa yang memperoleh manfaat. Egoisme etis melihat dari sudut pandang kepentingan individu, sedangkan paham utilitarianisme melihat dari sudut kepentingan orang banyak (kepentingan bersama, kepentingan masyarakat). Paham utilitarianisme dapat diringkas sebagai berikut:

- Tindakan harus dinilai benar atau salah hanya dari konsekuensinya (akibat, tujuan atau hasilnya).

- Dalam mengukur akibat dari suatu tindakan, satu-satunya parameter yang penting adalah jumlah kebahagiaan atau jumlah ketidakbahagiaan.

- Kesejahteraan setiap orang sama pentingnya.

\section{Kenakalan Remaja}

Indikator-indikator kenakalan remaja adalah seperti melarikan diri dari rumah, menggunakan narkoba, minum minuman keras, ikut tawuran dan berkelahi serta melakukan hubungan seks sebelum waktunya. Indikator-indikator tersebut sesuai dengan penelitian Papalia (2015). Papalia menyebutkan, kenakalan remaja mengacu pada rentang perilaku yang luas, mulai dari perilaku yang tidak dapat diterima secara sosial (seperti bertindak berlebihan di sekolah), adanya pelanggaran (seperti melarikan diri dari rumah atau melakukan free sex) hingga tindakan-tindakan kriminal (seperti mencuri) yang dilakukan oleh anak dan remaja. 


\section{Jenis dan Bentuk Kenakalan Remaja}

Papalia (2015) membedakan perilaku kenakalan ke dalam dua kategori yaitu index offenses dan status offenses. Index offenses merupakan tindakan kriminal baik yang dilakukan remaja maupun dewasa. Tindakan-tindakan itu meliputi perampokan, pencurian, pembunuhan, pemerkosaan. Status offenses merupakan tindakan-tindakan yang tidak terlalu serius dan melawan status di usianya, seperti membolos sekolah, lari dari rumah, mengonsumsi alkohol dan ketidakmampuan mengendalikan diri sehingga menimbulkan perkelahian.

\section{Faktor Penyebab Kenakalan Remaja}

Remaja dengan segala karakteristiknya yang khas mengarahkan remaja pada kondisi badai emosi dan stres yang mengguncang. Menurut Bandura, remaja menjadi suatu masa pertentangan dan pemberontakan karena terlalu menitikberatkan ungkapan-ungkapan bebas dan ringan dari ketidakpatuhan seperti mengubah model rambut atau memakai pakaian yang tidak senonoh. Keinginan dan keingintahuan akan sesuatu sehingga ingin rasanya mencoba muncul akibat pengamatan yang dilakukan pada orang dewasa (Gunarsa, 2017).

Penyebab kenakalan remaja dibagi menjadi tiga faktor: psikologis, biologis, sosiologis. Faktor psikologis merupakan faktor internal seperti cara pikir dan emosional yang tidak stabil yang menyebabkan kontrol diri yang kurang. Sesuai tugas perkembangannya, remaja seharusnya telah mempelajari perbedaan antara tingkah laku yang dapat diterima dan tingkah laku yang tidak dapat diterima, namun remaja yang melakukan kenakalan tidak mengenali hal ini. Hal ini membuat mereka memiliki anggapan yang salah, perilaku agresif, argumentatif berlebihan, menindas pihak yang lebih lemah, ketidakpatuhan, iritabilitas, tindakan mengancam yang tinggi.

Faktor biologis merupakan pengaruh elemen fisik dan organik dari remaja sendiri seperti tinggi atau rendahnya kadar hormonal, atau kekurangmatangan perkembangan salah satu bagian lobus otak. Jenis kelamin juga menjadi bagian ini. Erikson menjelaskan bahwa remaja lelaki cenderung lebih agresif dibanding remaja perempuan. Faktor sosiologis merupakan faktor eksternal seperti latar belakang keluarga, pengaruh teman sebaya, harapan terhadap pendidikan dan nilai-nilai sekolah, kelas sosial ekonomi, status di masyarakat serta kualitas masyarakat sekitar (Gunarsa, 2017). Oleh karena itu, penting untuk memberikan bimbingan dan konsistensi moral dari orang dewasa baik dalam lingkungan keluarga maupun lingkungan masyarakat agar para remaja yang tinggi dapat terarah kepada kegiatan yang positif, kreatif, dan produktif (Ali \& Asrori, 2015).

\section{Dampak Kenakalan Remaja}

Dampak yang dirasakan apabila kenakalan remaja tidak dapat teratasi. Di dalam keluarga, akan membuat hubungan keharmonisan antara remaja dengan kelurganya 
semakin memburuk. Seringkali remaja memandang orangtua mereka terlalu lamban, dan dalam banyak hal mereka lebih unggul ketimbang orangtua mereka.

Meskipun tidak salah, namun pandangan ini juga tidak sepenuhnya benar. Kebanyakan orangtua terlambat menyadari kondisi dan jalan pikiran anak remaja mereka sehingga menimbulkan konflik. Pada dunia pendidikan, remaja yang memasuki yang kurang berwatak baik dan melakukan kenakalan akan memberikan kesan kebebasan tanpa kontrol dari semua pihak terutama dalam lingkungan sekolah. Hal itu juga mengganggu tingkat prestasi anak itu sendiri dalam memahami pelajaran yang diberikan oleh pihak sekolah.

Pada dunia masyarakat, remaja yang melakukan kenakalan remaja biasanya lebih banyak menganggur sehingga akan menimbulkan peningkatan kejahatan bahkan timbulnya niat jahat di kalangan masyarakat. Di kalangan masyarakat sudah sering terjadi kejahatan seperti pembunuhan, penganiayaan, pemerkosaan, pemerasan, gelandangan dan pencurian.

Bagi mereka yang mengisi waktu senggangnya dengan bacaan-bacaan yang buruk (misalnya novel seks), maka hal itu akan berbahaya dan dapat menghalang halangi mereka untuk berbuat hal-hal yang baik. Demikian pula tontonan yang berupa gambar-gambar porno akan memberi rangsangan seks terhadap remaja, rangsangan seks tersebut akan berpengaruh negatif terhadap perkembangan jiwa anak remaja (Auliya, 2018)

\section{Pola Asuh Orangtua}

Pola asuh merupakan sejumlah model atau bentuk perubahan ekspresi dari orangtua yang dapat memengaruhi potensi genetik yang melekat pada diri individu dalam upaya memelihara, merawat, membimbing, membina dan mendidik anakanaknya baik yang masih kecil ataupun yang belum dewasa agar menjadi manusia dewasa yang mandiri dikemudian hari.

Pola asuh yang dilakukan setiap orangtua secara alami akan membentuk kepribadian seseorang, sehingga terjadi suatu perkembangan psikis pada diri individu untuk membentuk kepribadian yang berkarakter (Sonia,G. , 2020).

\section{Faktor yang Memengaruhi Pola Asuh Orangtua}

Ada beberapa faktor yang memengaruhi pola asuh yang diberikan orangtua yaitu pendidikan orangtua, lingkungan, dan budaya. Pendidikan orangtua yang berpengaruh terhadap persiapan orangtua dalam merawat dan mengasuh anak. Semakin tinggi pendidikan orangtua, semakin memudahkan orangtua mendapatkan informasi yang banyak mengenai pola asuh yang baik dan mengerti kebutuhan dalam memenuhi tumbuh kembang anak sehingga pola asuh yang diberikan semakin positif (Rosyidah, 2017). Lingkungan juga memengaruhi perkembangan anak, maka Lingkungan juga memengaruhi perkembangan anak, maka lingkungan juga ikut serta mewarnai pola pengasuhan orangtua. 
Budaya yang melekat pada lingkungan juga seringkali membuat orangtua mengikuti cara-cara yang dilakukan oleh masyarakat dalam mengasuh anak sebab orangtua mengharapkan kelak anaknya dapat diterima di masyarakat dengan baik (Abdullah, 2015).

Faktor lain yang memengaruhi pola asuh orangtua diantaranya: latar belakang pola pengasuhan orangtua sejak masa kecil dan status ekonomi serta pekerjaan orangtua yang memengaruhi fungsi orangtua dan dalam memperhatikan anak. Jenis kelamin anak juga memengaruhi keputusan orangtua dalam mendidik anak. Pada umumnya orangtua lebih ketat dalam memberi kebebasan kepada anak perempuan dan memberikan tanggung jawab lebih besar kepada anak laki-laki (Agustiawati, 2016).

\section{Solusi Mengatasi Perilaku Pola Asuh}

Perilaku pola asuh memengaruhi perkembangan dan pertahanan mental remaja dalam menyelesaikan masalah. Perilaku pola asuh terbagi menjadi dua fokus (Hoskins, 2014).

1. Perilaku Kontrol. Perilaku kontrol dalam pola asuh merupakan aktivitas dalam mengatur, mengelola, dan menyediakan petunjuk bagi anak untuk menentukan perilaku sosial yang tepat. Perilaku kontrol melibatkan proses pemantauan dan pendisiplinan. Pemantauan dilakukan dengan membantu kesadaran tentang perilaku yang tepat bagi remaja serta mendampingi perkembangan remaja. Pendisiplinan yang konsisten berhubungan dengan hasil yang positif pada perilaku remaja sedangkan pendisiplinan yang keras seperti mengancam, menakuti, dan menggunakan suara yang membentak sehingga berkontribusi menghasilkan perilaku yang agresif atau kekerasan.

2. Perilaku Pengasuhan. Perilaku ini melibatkan dukungan dan kehangatan dari orangtua dengan memberikan penjelasan terhadap pengasuhan yang diberikan dan memperhatikan interaksi dalam komunikasi antara orangtua dengan anak.

\section{Perilaku Moral}

Moral merupakan suatu yang digunakan untuk menentukan batas-batas dari sifat, perangai, kehendak, pendapat atau perbuatan yang secara layak dapat memberikan batasan terhadap aktifitas manusia dengan nilai (ketentuan) baik atau buruk, benar atau salah. Moral secara eksplisit terkait dengan proses sosialisasi individu, di mana tanpa moral manusia tidak bisa melakukan proses sosialisasi. Moral juga menjadi sifat dasar yang diajarkan di sekolah-sekolah dan siswa harus mempunyai moral jika ingin dihormati oleh sesamanya (Zainiyah, 2017).

Indikator-indikator perilaku moral pada keluarga broken home seperti harga diri yang rusak, perasaan yang terhina atau tersakiti, tidak dihargai oleh orangtua, menutup diri dan tidak bisa bersosialisasi dengan banyak orang. Indikator-indikator tersebut sesuai dengan penelitian Zainiyah (2017). Perilaku moral mengikuti kode moral kelompok masyarakat tertentu. Moral di sini berarti adat kebiasaan atau tradisi. 
Perilaku tidak bermoral berarti perilaku yang gagal mematuhi harapan kelompok sosial tersebut. Ketidakpatuhan ini disebabkan oleh ketidaksetujuan terhadap harapan kelompok sosial tersebut, atau karena kurang merasa wajib untuk mematuhinya. Perilaku di luar kesadaran moral adalah perilaku yang menyimpang dari harapan kelompok sosial yang lebih disebabkan oleh ketidakmampuan yang bersangkutan dalam memahami harapan kelompok sosial. Perkembangan moral ada hubungannya dengan tahap-tahap perkembangan intelektual seseorang, diasumsikan jika kemampuan pemahaman seseorang anak meningkat, maka tahap perkembangan moral anak tersebut juga meningkat.

\section{Perilaku Moral Bagi Remaja}

Moral berasal dari bahasa Latin. Bentuk tunggal kata 'moral' yaitu mos sedangkan bentuk jamaknya yaitu mores yang masing-masing mempunyai arti yang sama yaitu kebiasaan, adat (Amin, 2019, p. 16-17). Bila kita membandingkan dengan arti kata 'etika', maka secara etimologis, kata 'etika' sama dengan kata 'moral' karena kedua kata tersebut sama-sama mempunyai arti yaitu kebiasaan, adat. Dengan kata lain, kalau arti kata 'moral' sama dengan kata 'etika', maka rumusan arti kata 'moral' adalah nilai-nilai dan norma-norma yang menjadi pegangan bagi seseorang atau suatu kelompok dalam mengatur tingkah lakunya. Sedangkan yang membedakan hanya bahasa asalnya saja yaitu 'etika' dari bahasa Yunani dan 'moral' dari bahasa Latin.

Moral secara ekplisit adalah hal-hal yang berhubungan dengan proses sosialisasi individu tanpa moral manusia tidak bisa melakukan proses sosialisasi. Moral dalam zaman sekarang mempunyai nilai implisit karena banyak orang yang mempunyai moral atau sikap amoral itu dari sudut pandang yang sempit. Moral itu sifat dasar yang diajarkan di sekolah-sekolah dan manusia harus mempunyai moral jika ia ingin dihormati oleh sesamanya. Moral adalah nilai ke-absolutan dalam kehidupan bermasyarakat secara utuh. Penilaian terhadap moral diukur dari kebudayaan masyarakat setempat (Novita, 2021, p. 43).

Moral merupakan perbuatan atau tingkah laku atau ucapan seseorang dalam berinteraksi dengan manusia. apabila yang dilakukan seseorang itu sesuai dengan nilai rasa yang berlaku di masyarakat tersebut dan dapat diterima serta menyenangkan lingkungan masyarakatnya, maka orang itu dinilai mempunyai moral yang baik, begitu juga sebaliknya. Moral adalah produk dari budaya dan Agama. Moral juga dapat diartikan sebagai sikap, perilaku, tindakan, kelakuan yang dilakukan seseorang pada saat mencoba melakukan sesuatu berdasarkan pengalaman, tafsiran, suara hati, serta nasihat.

Orangtua yang tidak peduli dengan kehidupan anaknya dan sibuk dengan kesenangannya sendiri merupakan orangtua yang egois serta tidak bertanggung jawab terhadap kelangsungan generasi penerus bangsa. Karena dari situlah tumbuh degredasi moral anak-anak. Hal yang paling ditakuti, di mana moral bangsa terabaikan. dan apabila mereka berada dilingkungan yang salah, maka dengan tidak 
disadari akan mengambil jalan yang salah pula. Hal seperti ini selain akan merugikan diri sendiri, orangtua juga lingkungan masyarakat tempat tinggal.

\section{Faktor Penyebab Terjadinya Degradasi Moral}

Ada beberapa faktor yang menyebabkan terjadinya degradasi moral antara lain sebagai berikut.

\section{Penyimpangan Sosial}

Menurut James W.van der Zanden, "penyimpangan sosial merupakan perilaku yang oleh sejumlah besar orang dianggap sebagai suatu hal yang tercela dan di luar batas toleransi.penyimpangan sosial umumnya disebabkan oleh proses sosialisasi yang kurang sempurna". Retaknya sebuah rumah tangga menjadikan seorang anak tidak mengenal disiplin dan sopan santun. Hal ini di sebabkan karena orangtua sebagai agen sosialisasi tidak melakukan peran yang semestinya.

\section{Kurangnya Pengawasan dan Perhatian Orangtua}

Kemajuan ilmu pengetahuan dan teknologi tidak hanya mendorong para lakilaki untuk terjun kedalamnya bahkan para perempuan pun merasa memili hak yang sama untuk ikut terjun kedalamnya sehingga dalam sebuah rumah tangga seorang anak kurang mendapat pengawasan dan perhatian dari orangtua mereka ,akibatnya banyak dari mereka mncari kebahagiaan yang salah,seperti clumbing,minumminuman keras dan menghilangkan stres dengan obat-obatan.

\section{Kesibukan Orangtua}

Orangtua yang sibuk bekerja, orangtua yang sibuk bekerja sehingga tidak memiliki waktu bersama keluarga, semua keperluan anak diurus oleh pembantu, kebutuhan anak hanya dipenuhi oleh materi sehingga tidak ada bimbingan orangtua dan kehangatan keluarga yang diperlukan bagi pertumbuhan anak.

Orangtua sibuk menonton sinetron dari pagi hingga malam, sehingga anak yang pada awalnya mereka tidak mengetahui masalah percintaan, tetapi karena banyak orangtua yang menonton sinetron didepan anak mereka, akhirnya anak mereka pun jadi menyukai sinetron, sehingga yang ada di otak si anak hanya masalah cinta.

\section{Perceraian Orangtua}

Akibat perceraian orangtua akhirnya anak mencari jalan sendiri untuk memenuhi kebutuhannya dan menyenangkan dirinya tanpa peduli jalan yang diambil apakah benar atau salah. 


\section{Dampak Degradasi Moral}

1. Meningkatnya kekerasan pada Anak-anak

2. Penggunaan kata-kata yang memburuk

3. Pengaruh peer group (rekan kelompok) yang kuat dalam tindak kekerasan

4. Meningkatnya penggunaan narkoba, alkohol dan seks bebas

5. Kaburnya batasan moral baik-buruk

6. Menurunnya etos kerja

7. Rendahnya rasa hormat kepada orangtua dan guru

8. Rendahnya rasa tanggung jawab indvidu dan warga Negara

9. Membudayanya ketidakjujuran

10. Adanya saling curiga dan kebencian di antara sesama

\section{Solusi Mengatasi Degradasi Moral}

\section{Maksimalkan Peran Keluarga}

Keluarga merupakan kelompok sosial pertama dalam kehidupan manusia di mana ia belajar dan menyatakan diri sebagai manusia sosial di dalam hubungan interaksi dengan kelompoknya. Di dalam keluarga, manusia pertamatama belajar memperhatikan keinginan orang lain, belajar bekerja sama, bantu membantu, hingga penanaman etika dan moral. Dengan kata lain pengalaman interaksi sosial di dalam keluarga, turut menentukan pula cara-cara tingkah laku seseorang terhadap orang lain.

\section{Maksimalkan Peran Sekolah}

Sebagaimana kita ketahui bahwa Sekolah adalah tempat bagi Anak- anak untuk meningkatkan taraf intelegensinya. Namun demikan, seharusnya dalam hal ini sebuah Sekolah tidak hanya berperan sebagi peningkat taraf intelegensi Anak-anak semata, melainkan sebagai tempat pengoptimalan dan pemaksimalan sikap-sikap dan kebiasaan yang wajar yang telah di bentuk ketika berada di taman kanak-kanak hingga sekolah menengah.

\section{Maksimalkan Peran Media}

Media massa dalam hal ini seharusnya memberi asupan-asupan positif bagi mahasiswa, khususnya media yang menjadi konsumsi sehari-hari seperti televisi, surat kabar, dan semacamnya. Dan bagi mahasiswa itu sendiri seharusnya mampu cerdas dalam bermedia.

\section{Pemanfaatan Substansi Teknologi Secara Tepat}

Teknologi seharusnya diciptakan demi kemaslahatan umat dan bukan sebaliknya. Maka pemanfaatan substansi teknolgi pada cara yang tepat adalah 
penting demi tegaknya nilai-nilai positif terutama nilai-nilai agama dan moral dalam berkehidupan.

\section{Pengaruh Perilaku Moral Keluarga Broken Home terhadap Kenakalan Remaja}

Moral juga menjadi sifat dasar yang diajarkan di sekolah-sekolah dan siswa harus mempunyai moral jika ingin dihormati oleh sesamanya (Zainiyah, 2017). Indikator-indikator perilaku moral seperti harga diri yang rusak, perasaan yang terhina atau tersakiti, tidak dihargai oleh orangtua, menutup diri dan tidak bisa bersosialisasi dengan banyak orang. Indikator-indikator tersebut sesuai dengan penelitian Zainiyah (2017).

Solusi yang terbaik atas indikator-indikator perilaku moral yang sering memicu kenakalan remaja untuk generasi mendatang bisa dilakukan dengan memaksimalkan peran orangtua seperti perhatian khusus dari orangtua serta pola asuh yang baik terhadap anaknya, dengan memaksimalkan peran sekolah seperti adanya sosialisasi atau hubungan belajar dan mengajar tentang perilaku moral baik yang harus dilakukan oleh setiap muridnya serta memaksimalkan peran penggunaan media seperti adanya pembatasan konten-konten yang menjurus perilaku moral yang menyimpang harus diblokir.

Semakin merosotnya perilaku moral anak di keluarga broken home maka semakin banyak kenakalan remaja yang dilakukannya di luar rumah. Sebaliknya walaupun keluarganya mengalami broken home, tetapi seorang anak atau remaja bisa mempertahankan perilaku moralnya dengan baik dan berpikiran positif agar di masa depannya, remaja tersebut tidak akan seperti orangtuanya. Dengan demikian, semakin kecil kenakalan remaja yang terjadi.

\section{Pengaruh Pendidikan Karakter Keluarga Broken Home Terhadap Kenakalan Remaja}

Pendidikan karakter dapat dimaknai sebagai pendidikan budi pekerti, pendidikan moral, pendidikan nilai, pendidikan watak, yang bertujuan untuk mengembangkan kemampuan peserta didik dalam menentukan baik dan buruk, memelihara apa yang baik dan mengaplikasikan kebaikan tersebut dalam kehidupan sehari-hari (Cahyo, 2017).

Indikator-indikator pendidikan karakter pada keluarga broken home seperti melarikan diri dari rumah, menggunakan narkoba, minum minuman keras, ikut tawuran dan berkelahi serta melakukan hubungan seks sebelum waktunya. Indikatorindikator tersebut sesuai dengan penelitian Papalia (2015)

Solusi yang terbaik atas indikator-indikator pendidikan karakter yang sering memicu kenakalan remaja untuk generasi mendatang bisa dilakukan seperti menciptakan komunikasi yang baik dalam keluarga dan menanamkan kejujuran sejak dini dengan mengajak anak untuk membaca Firman Tuhan, mengajarkan anak untuk memuji dan menyembah kepada Tuhan melalui pujian dan penyembahan, diadakannya komsel anak agar dapat bersosialisasi dengan orang banyak dengan 
berbagai macam latar belakang, mengajarkan kepada anak untuk disiplin dalam mengerjakan tugasnya dan belajar bertanggung jawab.

Semakin baik seorang remaja memperoleh pendidikan karakter maka semakin baik pula budi pekerti remaja tersebut sehingga semakin kecil kenakalan remaja yang terjadi di luar rumah.

\section{METODE}

Penelitian ini menggunakan wawancara singkat dengan 50 Kepala Keluarga Broken Home di Jakarat Barat pada bulan Juli 2021 dan penelitian ini bersifat kualitatif berupa riset kepustakaan ini menggunakan metode analisis isi (content analisys). Isi setiap materi berupa buku, jurnal, atau artikel yang relevan dengan topik yang berhasil dikumpulkan di telaah, dianalisis, dan disintesis guna membentuk konsep yang lengkap dalam menjawab pertanyaan penelitian.

\section{HASIL DAN PEMBAHASAN}

\section{Pendidikan Karakter bagi Remaja}

Permasalahan yang terjadi akhir-akhir ini, khususnya terkait kenakalan remaja, seperti seks bebas, narkoba, pergaulan bebas dan bullying makin meningkat. Tentunya, permasalahan ini akan memengaruhi merosotnya moral generasi muda, yang digadang-gadang sebagai tonggak atau penentu masa depan bangsa. Oleh karena itu, masalah krisis moral harus segera diatasi dan dicegah sedini mungkin salah satunya dengan pendidikan karakter.

Pendidikan karakter merupakan pendidikan terhadap konsep moral, sikap moral, dan perilaku moral. Berdasarkan tiga konsep tersebut maka pendidikan karakter memiliki pemahaman bahwa karakter yang baik mampu didapat dan didukung dari pengetahuan tentang kebaikan, keinginan untuk berbuat baik dan melakukan perbuatan baik.

Dalam menerapkan pendidikan karakter tentunya tidak bisa lepas dari peran orangtua, pendidik/guru, masyarakat/lingkungan, dan pemerintah, oleh sebab itu ada beberapa aspek yang sebaiknya diperhatikan.

\section{Aspek Pendidikan Orangtua}

Orangtua memegang peran yang penting dalam mendidik dan mengarahkan anak mencapai cita-cita dan keinginannya, untuk itu mananamkan pendidikan karakter harus terus dilakukan dengan memberikan pemahaman kepada anak akan nilai-nilai moral yang sesuai dengan budaya bangsa seperti sifat religius, jujur, toleransi, disiplin, kerja keras, kreatif, cinta tanah air, peduli terhadap lingkungan, sosial, dan tanggung jawab.

Untuk itu komunikasi yang baik harus mampu terjalin, selain itu pengawasan orangtua harus selalu dilakukan namun jangan sampai membuat anak merasa 
kehilangan privasi mereka. Pengawasan artinya memperhatikan dan menganalisis tingkah laku anak, jika dirasa ada yang menyimpang dari tingkah laku anak, maka tugas orangtua adalah mengingatkan dan mengarahkan anak sebelum terlambat.

Selain itu memperhatikan lingkungan pergaulan anak sangat penting menjadi perhatian orangtua, karena tumbuh kembang anak juga dipengaruhi oleh lingkungan dan pemilihan teman bergaul yang tepat. Hal yang paling dasar dan penting ialah memberikan pemahaman agama untuk meningkatkan iman dan ketakwaan anak.

\section{Aspek Pendidikan (Sekolah)}

Sekolah menjadi media dan sarana pendidikan yang sangat penting setelah peran didik orangtua. Sekolah menjadi tempat memperluas wawasan dan pengetahuan dalam kehidupan sosial, untuk itu peran pendidik sangat penting dalam memberikan pemahaman kepada murid tentang pentingnya memanfaatkan ilmu pengetahuan dan teknologi dengan baik.

Selain itu menerapkan pendidikan karakter juga bisa dilakukan melalui sistem pendidikan terpadu di dalam kelas pada setiap mata pelajaran yang diajarkan, artinya proses belajar mengajar tidak hanya dilakukan melalui satu arah sebatas guru kepada murid, tetapi proses belajar yang turut serta melibatkan murid dalam menyelesaikan kasus atau masalah, dengan kata lain terjadi interaksi dua arah yang saling memengaruhi antara murid dan guru.

Hal ini bertujuan agar peserta didik mampu memahami dengan baik apa yang dimaksud dengan pendidikan karakter. Penerapan kurikum terpadu mengajak peserta didik untuk ikut serta memahami model pendidikan yang baik dan diajak untuk bertindak langsung.

\section{Aspek Regulasi Pemerintah dan Hukum}

Keberhasilan dalam mengatasi krisis moral pada generasi muda akan sulit dicapai tanpa peran serta pemerintah dalam menegakkan aturan hukum dan penerapan kurikulum pendidikan yang baik. Peran pemerintah yang dimaksud adalah senantiasa memperbaiki kurikulum pendidikan dan yang paling penting adalah pemerataan pendidikan di seluruh negeri. Dari segi aspek hukum, pemerintah juga harus turun tangan dalam penegakan hukum seperti kasus korupsi, suap, dan tindak kejahatan kriminal lainnya. Pemberian sanksi yang tegas dalam menangani setiap kasus tanpa memandang status, jabatan harus dilakukan pemerintah.

Hal tersebut tentu tidak mudah, untuk itu perlu komitmen dan sanksi yang tegas dari pemerintah dalam menegakkan aturan dikalangan aparatur negara, misalnya mencabut status jabatan atau memberi sanksi berat. Hal ini penting sebagai efek jera mengingat semakin banyak kasus kolusi, dan nepotisme yang dapat menjadi contoh tidak baik bagi masyarakat dan ikut memengaruhi moral generasi muda dalam memandang bangsanya. 


\section{Membudayakan Nilai-nilai Moral dan Agama}

Dalam hal ini perlu kejasama seluruh pihak, baik dari orangtua, pendidik, pemerintah, dan seluruh elemen masyarakat untuk sama-sama mau berkomitmen membudayakan moral berbangsa yang berlandaskan Pancasila sehingga tercipta keharmonisan hidup dan lingkungan yang religius sesuai dengan karakter bangsa.

Setelah membahas beberapa solusi dalam memperbaiki moral generasi bangsa dengan pendidikan karakter, peneliti juga memberikan indikator keberhasilan dalam penerapan pendidikan karakter sebagai berikut:

- Generasi muda mampu memahami kekurangan dan kelebihan dirinya sebagai anugerah dari Tuhan yang wajib disyukuri

- Adanya sikap percaya diri

- Menurunnya pelanggaran terhadap aturan sosial yang berlaku di masyarakat

- Generasi muda mampu menunjukkan pemikiran yang logis dan kreatif

- Mampu menunjukkan kemandirian sesuai kemampuan yang dimiliki

- Mampu menunjukkan cara komunikasi yang baik dan santun

- Mampu menunjukkan rasa menghargai hak dan kewajiban dalam bergaul di masyarakat

- Mampu menunjukkan sikap menyimak dan keterampilan membaca, menulis dan bicara

- Dan yang lebih penting di atas segalanya adalah bagaimana pendidikan generasi muda mampu sejalan dengan cita-cita pendidikan Indonesia

Berdasarkan materi pembelajaran diatas, maka tanggapan dan respon dari hasil wawancara 50 kepala keluarga broken home atas diberlakukannya sejak dini pendidikan perilaku moral dan pendidikan karakter untuk anak remaja dalam mengatasi masalah kenakalan anak remaja sebagai berikut.

Tabel 1. Descriptive Statistics

\begin{tabular}{cccc}
\hline N & Valid & $\begin{array}{c}\text { Pendidikan } \\
\text { Perilaku Moral }\end{array}$ & $\begin{array}{c}\text { Pendidian } \\
\text { Karakter }\end{array}$ \\
\hline Frequency & 50 & 50 \\
Mean & $85 \%$ & $85 \%$ \\
Median & 40,8718 & 40,7949 \\
Standar Deviation & 41,0000 & 41,0000 \\
\hline Minimum & 2,53584 & 2,54620 \\
\hline Maksimum & 36 & 36 \\
\hline
\end{tabular}

Sumber: Data diolah Juli 2021

Berdasarkan tabel di atas maka informasi yang diperoleh Hasil wawancara singkat dengan 50 Kepala Keluarga Broken Home menyatakan bahwa 85\% mereka setuju bahwa pendidikan perilaku moral dan pendidikan karakter sangat penting bagi 
anak remaja dan dibutuhkannya juga peran guru di sekolah selain dari peran orangtua yang didasarkan dengan indikator-indikator perilaku moral seperti harga diri yang rusak, perasaan yang terhina atau tersakiti, tidak dihargai oleh orangtua, menutup diri dan tidak bisa bersosialisasi dengan banyak orang.

$\mathrm{Hal}$ ini berarti solusi yang terbaik atas indikator-indikator perilaku moral yang sering memicu kenakalan remaja untuk generasi mendatang bisa dilakukan dengan memaksimalkan peran orangtua seperti perhatian khusus dari orangtua serta pola asuh yang baik terhadap anaknya, dengan memaksimalkan peran sekolah seperti adanya sosialisasi atau hubungan belajar dan mengajar tentang perilaku moral baik yang harus dilakukan oleh setiap muridnya serta memaksimalkan peran penggunann media sepeti adanya pembatasan konten-konten yang menjurus perilaku moral yang menyimpang harus diblokir. Solusi yang terbaik atas indikator-indikator pendidikan karakter yang sering memicu kenakalan remaja untuk generasi mendatang bisa dilakukan seperti menciptakan komunikasi yang baik dalam keluarga dan menanamkan kejujuran sejak dini dengan mengajak anak untuk membaca Firman Tuhan, mengajarkan anak untuk memuji dan menyembah kepada Tuhan melalui pujian dan penyembahan, diadakannya komsel anak agar dapat bersosialisasi dengan orang banyak dengan berbagai macam latar belakang, mengajarkan kepada anak untuk disiplin dalam mengerjakan tugasnya dan belajar bertanggung jawab.

Semakin merosotnya perilaku moral anak di keluarga broken home maka semakin banyak kenakalan remaja yang dilakukannya di luar rumah. Sebaliknya walaupun keluarganya mengalami broken home, tetapi seorang anak atau remaja bisa mempertahankan perilaku moralnya dengan baik dan berpikiran positif agar di masa depannya, remaja tersebut tidak akan seperti orangtuanya maka semakin kecil kenakalan remaja yang terjadi. Semakin baik seorang remaja memperoleh pendidikan karakter maka semakin baik pula budi pekerti remaja tersebut sehingga semakin kecil kenakalan remaja yang terjadi di luar rumah.

\section{KESIMPULAN}

Peran orangtua termasuk keluarga yang broken home merupakan hal terpenting dalam mengedukasi masalah remaja. Melalui orangtua, remaja diberikan dasar pendidikan perilaku moral yang baik, dan pendidikan karakter untuk usia remaja sangat diperlukan saat ini. Lingkungan juga turut mendukung dalam menjadikan pribadi remaja yang cukup baik. Lingkungan tersebut bisa berasal dari lingkungan tempat tinggal dan lingkungan sekolah. Peran Guru di lingkungan sekolah juga sangat penting dalam memberikan pembentukan perilaku moral yang baik dan pendidikan karakter yang berkepribadian yang baik dalam mencegah kenakalan remaja. Dalam penelitian ini bahwa peran orangtua dan guru atas perilaku moral dan pendidikan karakter masih sangat berpengaruh bagi keluarga broken home terhadap kenakalan remaja. 


\section{KEPUSTAKAAN}

Abdullah, N. (2015). Hubungan Pola Asuh Orangtua Dengan Konsep Diri Anak Usia Sekolah. Malang: Program Studi Magister Universitas Muhammadiyah Malang. Agustiawati, Isni. (2014). Pengaruh Pola Asuh Orangtua terhadap Prestasi Belajar Siswa pada Mata Pelajaran Akuntansi Kelas XI IPS di SMA Negeri 26 Bandung (Skripsi, Universitas Pendidikan Indonesia). http://repository.upi.edu/12418/.

Ali, M., \& M. Asrori (2015). Psikologi Remaja: Perkembangan Peserta Didik. Jakarta: Bumi Aksara.

Amin, Saifuddin. (2019). Etika Peserta Didik Menurut Syaikh Muhammad Bin Shalih AlUtsaimin. Yogyakarta: Deepublish.

https://books.google.co.id/books?id=OQSNDwAAQBAJ\&printsec=frontcover\&s ource $=g b s \_a t b \# v=$ onepage $\& q \& f=$ false.

Auliya, R. U. (2018). Kenakalan Orangtua Penyebab Kenakalan Remaja. Jurnal Al-

Taujih, 4(2), 92-103.

https://ejournal.uinib.ac.id/jurnal/index.php/attaujih/article/view/505/422.

Bertens, K. (2013). Etika (Seri Filsafat Atmajaya). Yogyakarta: Kanisius.

Cahyo, D. E. (2017). Pendidikan Karakter Guna Menanggulangi Dekadensi Moral Yang Terjadi Pada Siswa Sekolah Dasar. EduHumaniora: Jurnal Pendidikan Dasar, 9(1), 14-26. https://ejournal.upi.edu/index.php/eduhumaniora/article/view/6150.

Erlinda. (2017). Data Statistik Komisioner Komisi Perlindungan Anak Indonesia (KPAl). Gunarsa, S. (2017). Psikologi Perkembangan Anak dan Remaja. Jakarta: Gunung Mulia. Hoskins, Donna H. (2014). Consequences of Parenting on Adolescent Outcomes. Societies, 4(3), 506-531. https://www.mdpi.com/2075-4698/4/3/506.

Novita, Nesi. (2021). Sosial Budaya Dasar dalam Praktik Kesehatan dan Kebidanan.

Yogyakarta: Bintang Pustaka Madani.

https://www.google.co.id/books/edition/Sosial_Budaya_Dasar_dalam_Praktik_Ke seha/SSglEAAAQBAJ?hl=en\&gbpv $=1$.

Papalia, D. E. (2015). Menyelami Perkembangan Manusia. Jakarta: Salemba Medika. Rosyidah, N. (2017). Hubungan Pola Asuh Orangtua Terhadap Kenakalan Remaja Pada Siswa SMK yayasan Cengkareng Dua Jakarta Barat (Skripsi, UIN Syarif Hidayatullah Jakarta: Fakultas Kedokteran dan Ilmu Kesehatan). http://repository.uinjkt.ac.id/dspace/handle/123456789/36741.

Sonia, G. dan N. C. Apsari. (2020). Pola Asuh Yang berbeda-beda dan Dampaknya Terhadap Perkembangan Kepribadian Anak. Jurnal Prosiding Penelitian dan Pengabdian Kepada Masyarakat, 7(1), 128-135.

http://jurnal.unpad.ac.id/prosiding/article/view/27453.

Unayah, N dan S. Muslim. (2015). Fenomena Kenakalan Remaja dan Kriminalitas. Sosio Informa, 1(2).

https://ejournal.kemensos.go.id/index.php/Sosioinforma/article/view/142/89.

Wahid, Abdul. (2014). Konsep Orang tua Dalam Membangun Kepribadian Anak. Jurnal Paradigma Institut, 1(1). 
http://ejournal.kopertais4.or.id/mataraman/index.php/paradigma/article/view/8 98

Zainiyah, K. (2017). Pendidikan Moral Anak Pada Keluarga Broken Home (Studi Kasus di Desa Pucangrejo Kecamatan Gemuh Kabupaten Kendal Tahun 2017) (Skripsi, IAIN Salatiga). http://e-repository.perpus.iainsalatiga.ac.id/1826/. 